\title{
A INSTITUCIONALIZAÇÃO DOS ESTUDOS DE MULHERES, GÊNERO E FEMINISMO EM TEMPOS DE DITADURA MILITAR
}

\author{
The Institutionalization of Women, Gender and Feminist Studies in \\ Times of Military Dictatorship
}

Gabriela de Brito Caruso'

\begin{abstract}
Resumo
Este artigo trata da institucionalização dos Estudos de Mulheres, Gênero e Feminismo nas Ciências Sociais brasileiras no contexto da ditadura militar (1964-1985). 0 objetivo é discutir a construção da área de estudos a partir das disputas e estratégias intelectuais para legitimação de seu status epistêmicos em um contexto político autoritário. Para tal, selecionamos e analisamos algumas das principais produções acadêmicas que fazem uma revisão do processo histórico, observando como a área organiza as narrativas que produz sobre si mesma. A partir destas narrativas, elencamos os principais condicionantes que influenciaram o modo como a área se desenvolveu no Brasil, majoritariamente como uma subárea do conhecimento atrelada a disciplinas mais tradicionais. Destacase o vazio político resultante da repressão, a reforma universitária do período militar e as alianças pela democracia como pano de fundo para uma estratégia que se utiliza das credenciais científicas das Ciências Sociais na legitimação dos Estudos de Mulheres, Gênero e Feminismo no meio acadêmico.
\end{abstract}

Palavras-chave: Feminismo, Institucionalização, Estudos de Mulheres, Estudos de Gênero, Ditadura Militar

\begin{abstract}
This article deals with the institutionalization of Women, Gender and Feminist Studies in the Brazilian Social Sciences and its narratives in the context of the military dictatorship. The aim is to think about the construction of an area of studies as from the disputes and intellectual strategies to legitimize their epistemic status in an authoritarian political context. To pursue this, we select and analyze some of the main academic productions that reviews the historical process, observing how the area organizes the narratives it produces about itself. From these narratives, we list the main conditions that influenced the way the area developed in Brazil, mostly as a subarea of knowledge linked to more traditional disciplines. The political vacuum resulting from repression, the university reform of the military period and the alliances for democracy are a background for a strategy that uses the scientific credentials of the Social Sciences in the legitimization of the Women, Gender and Feminist Studies in academy.
\end{abstract}

Keywords: Feminism, Institutionalization, Women's Studies, Gender Studies, Military Dictatorship

\section{Introdução}

\footnotetext{
1 Doutoranda em Sociologia e pesquisadora do Núcleo de Estudos de Teoria Social e América Latina (NETSAL) no Instituto de Estudos Sociais e Políticas na Universidade do Estado do Rio de Janeiro (IESP-UERJ). http://lattes.cnpq.br/2110273097086046
} 
A institucionalização dos estudos de mulheres, gênero e feminismo em tempos de ditadura militar | Gabriela de Brito Caruso

Existe extensa bibliografia sobre a institucionalização dos Estudos de Mulheres, Gênero e Feminismo (EMGF) no mundo. Ainda que tal abordagem seja comum em relação a diferentes disciplinas e áreas, o tema é particularmente caro aos EMGF pelos seguintes motivos: é uma área relativamente nova, com pouco mais de meio século desde seu surgimento na academia; é pouco homogênea, com fortes traços interdisciplinares; e, por fim, tem raízes históricas em movimentos sociais e políticos. Todos estes fatores se constituem como obstáculos para que os EMGF reivindiquem a pertinência de seu status epistêmico junto aos marcadores de produção de conhecimento científico nas universidades e centros de pesquisa.

Este artigo se dedica a entender a institucionalização dos EMGF nas Ciências Sociais brasileiras a partir das estratégias empreendidas na construção da sua legitimidade científica durante o contexto da ditadura militar (1964-1985). Para tal, busca esquivar de uma sociologia dos intelectuais que dá demasiado foco às relações pessoais entre os atores e à autonomia de campos de conhecimento. O intuito é observar a formação de uma área de estudos a partir da relação dos intelectuais com o contexto político e social da época, as visões de mundo que conservavam, bem como a leitura que faziam dos acontecimentos e da sociedade brasileira.

Esta abordagem se prova ainda mais acertada quando falamos da área dos EMGF, especialmente no Brasil, dado o envolvimento de grande parte de suas pioneiras na atuação pública, seja, como dito, em movimentos sociais e organizações não-governamentais (ONGs), ou em secretarias e governos. O discurso sociológico é reformulado a todo instante por reflexões e entendimentos produzidos fora de seus limites organizacionais, mas a incorporação destes discursos às Ciências Sociais depende de como essa comunidade se organiza, e da capacidade destes discursos de produzir reconhecimento no meio acadêmico (HEILBORN, SORJ, 1999).

É relativamente consensual entre as estudiosas do tema no Brasil que o contexto de endurecimento e flexibilização do Regime Ditatorial e a luta pela democracia são definidores do trajeto feminista brasileiro (COSTA, 1988, 1994; PEDRO, 2006 e SARTI, 2001, entre outras). No entanto, este não parece ser apenas um desdobramento contextual, a trajetória da área 
A institucionalização dos estudos de mulheres, gênero e feminismo em tempos de ditadura militar | Gabriela de Brito Caruso

também pode ser demarcada por uma recusa ativa e consciente da via institucional acadêmica autônoma, o que será retomado na sequência.

Um dos marcadores do caso brasileiro é que a pesquisa acadêmica nos EMGF não levou a um processo de disciplinização, ou seja, não se tornou uma disciplina com cursos regulares e diplomas de graduação no ensino superior brasileiro, como é o caso nos Estados Unidos (HEILBORN, SORJ, 1999). Aqui, os EMGF se institucionalizaram pelas beiradas, recusando a construção de um cerne acadêmico até ao menos meados da década de 1990. A pesquisa se desenvolveu a despeito da não implementação de ensino e treinamento sistemático de profissionais. Esta configuração não é incomum quando olhamos a literatura sobre institucionalização da área ao redor do mundo (PEREIRA, 2017), mas destoa em relação ao modelo norte-americano que, além de ser uma das influências do feminismo no Brasil, é um dos principais centros de produção e circulação de conhecimento científico, sobretudo nos EMGF.

A institucionalização da área nas Ciências Sociais brasileiras se concentrou na pesquisa em detrimento do ensino, com financiamento marcado pelas agências internacionais, construindo redes que se manifestaram institucionalmente a partir de núcleos de estudos, bolsas, congressos e revistas acadêmicas. No Brasil, os EMGF não se constituíram como uma área de ensino, específica de formação, sendo majoritariamente conduzidos dentro de disciplinas mais tradicionais, como uma subárea do conhecimento. Isto não impediu que revistas acadêmicas e congressos se desenvolvessem e adquirissem legitimidade no meio acadêmico. De forma menos vinculada à estrutura acadêmica, a área também se institucionalizou a partir de centros, ONGs e através de algumas entradas e conquistas no governo brasileiro sobretudo a partir da redemocratização e da Constituição de 1988.

Os EMGF têm suas primeiras produções ainda na década de 1960, vindo a despontar no espaço acadêmico brasileiro a partir dos anos 1970, preferencialmente nas áreas das Ciências Humanas e Sociais, uma tendência também identificada na experiência dos países centrais (COSTA; BARROSO; SARTI, 1985). A série "Bibliografias Anotadas/Mulher brasileira”, volumes 1 e 2, (FUNDAÇÃO CARLOS CHAGAS, 1979 e 1981) contabiliza 
A institucionalização dos estudos de mulheres, gênero e feminismo em tempos de ditadura militar | Gabriela de Brito Caruso

apenas 2 mestrados, 2 doutorados e uma livre docência na área no período anterior a década de 1970. Segundo a mesma publicação e o estudo realizado por Costa, Barroso e Sarti (1985), há expressiva expansão desde então: são 17 mestrados e 8 doutoramentos entre 1970 e 1974; de 1975 à 1979, 54 mestrados e 5 doutoramentos e, por fim, 61 de mestrados e 20 doutoramentos de 1980 ao primeiro semestre de 1984. No entanto, como nos alertam as autoras, os dados devem ser matizados também pela concomitante expansão da pós-graduação e da institucionalização das Ciências Sociais no Brasil.

A área dos EMGF nos anos 1970 foi interpretada pelas especialistas da época como um limbo (ver COSTA; BARROSO; SARTI, 1985), onde as pesquisadoras viviam entre provar a cientificidade de suas atividades para a comunidade acadêmica e as agências de financiamento e provar a suas colegas feministas seu empenho na causa coletiva e não na construção de sua carreira pessoal profissional. Eram feministas aos olhos da academia e acadêmicas aos olhos das feministas, trabalhando em uma zona fronteiriça de tensão e ambiguidade (COSTA; BARROSO; SARTI, 1985). Vamos observar que esta tensão entre "pesquisadoras" e "militantes" também aparece em outros depoimentos e análises da área.

Tematicamente, predominava no boom das pesquisas sobre mulheres no final da década de 1970 análises direcionadas às relações de produção. Mulher e trabalho, no espaço urbano ou rural, marcam o início da investigação acadêmica (SILVA, 2000), como os trabalhos das sociólogas e pioneiras Heleieth Saffioti (1976 [1969]) e Eva Altermann Blay (1978).

Nos anos 1980, segue aumentando de forma vertiginosa a produção dos EMGF concentrando grande poder de atração, e impacto no mundo acadêmico brasileiro. As temáticas diversificam e é a partir deste momento que se destacam as pesquisas sobre a heterogeneidade das experiências, com os trabalhos pensando o carácter relacional entre os sexos, construído socialmente a partir de relações de poder, que fomentam hierarquias e conduzem à desigualdade social (SILVA, 2000). Finalmente, entram em pauta as questões relativas aos direitos reprodutivos, com demógrafas e sociólogas como Elza Berquó e Carmem Barroso, analisando a queda da 
A institucionalização dos estudos de mulheres, gênero e feminismo em tempos de ditadura militar | Gabriela de Brito Caruso

fecundidade no país e denunciando a prática indiscriminada da esterilização feminina (SILVA, 2000).

Os anos de 1990, de maneira geral, são entendidos como o momento de consolidação da área. É quando são criadas as principais revistas acadêmicas nacionais (Revista Estudos Feministas e Cadernos Pagu), que contribuíram para uma institucionalização mais expressiva dos EMGF, trazendo maior legitimação para a área e abrindo espaço para a ampliação do escopo dos trabalhos produzidos ${ }^{2}$. A expansão de temas trabalhados dentro dos EMGF e a progressiva articulação de redes feministas nos anos 1990 impulsionam a especialização dos estudos nesta área, que se refletirá nos anos 2000 em diante com ganhos em diversificação, desenvolvimento e institucionalização.

O objetivo deste trabalho é elaborar de forma mais sistemática as razões desta trajetória, observando as estratégias empreendidas na negociação da legitimidade, tanto da área de estudos quanto das pautas dos movimentos de mulheres e feministas. O intuito é elaborar uma análise sobre o que seria um modelo de institucionalização adotado pelas acadêmicas brasileiras dos EMGF nas Ciências Sociais dos anos 60 até 1990. Encerramos nossa análise em 1990 pois nos concentramos no processo que possibilita a institucionalização da área, que se dá de fato no decorrer dos anos 90.

\section{O quanto conta o contexto}

Em termos do projeto acadêmico dos EMGF, esta condição dual de estar presente na academia ao mesmo tempo que fugindo dos marcadores institucionais da área torna deveras complicada uma análise sistemática. Por isso trataremos da história dos EMGF dentro do recorte das Ciências Sociais, com uma atenção maior à sociologia, ainda que seja inescapável olhar além destas fronteiras. Meu argumento, apoiado na literatura corrente sobre o tema, é que, no contexto de sua expansão, três conjuntos de fatores contextuais foram definidores nos rumos dos EMGF, sendo eles:

2 Como o recorte temporal deste artigo se esgota em1990, preferimos não tratar em detalhes da importância das revistas científicas criadas nesta década para a constituição do campo. Para tal bibliografia, consultar Piscitelli, Beleli e Lopes (2003), Grossi (2004), Lopes e Piscitelli (2004) e Maluf (2004). 
A institucionalização dos estudos de mulheres, gênero e feminismo em tempos de ditadura militar | Gabriela de Brito Caruso

1) A resistência a um regime ditatorial militar e a redemocratização do país;

2) A influência internacional e as adaptações locais, amplificadas por dois tipos de experiências, a do exílio e a da formação estrangeira por parte da elite intelectual;

3) A reforma universitária e a expansão e sedimentação das Ciências Sociais no Brasil.

Neste artigo nos deteremos no primeiro ponto, buscando esmiuçar a influência do contexto político ditatorial militar na concepção de movimento de mulheres e como isto se traduziu na entrada acadêmica dos EMGF na universidade. Faremos isto observando como são mobilizados três temas nas narrativas dos EMGF: (a) o regime militar e a repressão; (b) a resistência e os movimentos sociais; e (c) as narrativas acadêmicas. Para isso, analiso um conjunto de textos que em seu argumento principal tratam a história, da institucionalização ou fazem uma reflexão acerca da área até os anos 1990 (como BLAY, CONCEIÇÃO, 1991; CORRÊA, 2001; COSTA, 1988, 1994; COSTA, BARROSO, SARTI, 1985; SARTI, 1988; COSTA, SARDENBERG, 1994; HEILBORN, SORJ, 1999; entre outras). São textos produzidos entre 1985 e 2005 que propõe analisar ou comentar os EMGF ou o feminismo e sua vertente acadêmica no Brasil.

Dei preferência a textos de autoras que participaram enquanto agentes deste momento pioneiro para observar como as mesmas elaboraram suas narrativas sobre a área. Destarte, um certo cuidado deve ser tomado nesta análise para, como nos chama atenção Cynthia Sarti (2001), observar o feminismo como uma experiência histórica que enuncia genérica e abstratamente a emancipação feminina, mas que também atua dentro dos limites e das possibilidades quando nos referimos concretamente a mulheres em contextos políticos, sociais, culturais e históricos específicos.

Por isto é necessário ter em mente o que nos fala Chandra Mohanty em Under Western Eyes (2003), que nos lembra dos cuidados que devemos tomar em nossas análises para não colonizar discursivamente mulheres não-ocidentais do Terceiro Mundo como um “outro" coletivo. Portanto, em vez de olhar as mulheres brasileiras através de termos e classificações monolíticas, rotulando-as como pobres, sem instrução, ligadas à tradição ou 
A institucionalização dos estudos de mulheres, gênero e feminismo em tempos de ditadura militar | Gabriela de Brito Caruso

vitimadas, por exemplo, pela ditadura militar e as pelas mazelas do Terceiro Mundo, concentro-me na complexidade, diversidade e multiplicidade das mulheres que construíram os EMGF no Brasil.

Isso é importante, na medida em que não quero sugerir que o EMGF nos Estados Unidos (que desde o começo teve grande ênfase no ensino, com a criação de graduações em Women Studies) seja um modelo que o Brasil deveria seguir, mas que não alcançou. Precisamente porque isso levaria a pressupostos subjacentes de que o que é produzido no centros de produção de conhecimento é melhor, que sua maneira de organizar o ensino e a pesquisa acadêmica são melhores, que as mulheres ocidentais são mais liberadas, inteligentes, educadas e gozam de maior igualdade, enquanto as mulheres do "Terceiro Mundo" precisam de ajuda ou orientação em suas lutas emancipatórias (MOHANTY, 2003). Ao reconhecer que há política e poder na prática discursiva e na produção de conhecimento, busco abordar criticamente a produção científica sobre a institucionalização da EMGF, a fim de identificar como é enquadrada sua constituição histórica pelas narrativas das próprias agentes participantes do processo.

A revisão feita por Maria Pereira (2017) sobre os trabalhos que tematizaram o desenvolvimento dos EMGF ajuda a sustentar a importância de alguns fatores contextuais no Brasil. Segundo Pereira (2017), o contexto político tem sido descrito como desempenhando um papel decisivo, com pesquisas mostrando que a institucionalização tende a ser mais forte e apoiada onde e quando o Estado considera a promoção da igualdade de gênero uma área fundamental de intervenção. Além disso, os regimes conservadores e autoritários tendem a não prestar apoio e, às vezes, são hostis à pesquisa e à educação nos EMGF. A literatura indica que a queda de tais regimes pode abrir o caminho para a expansão do campo. O primeiro fator contextual que sugiro ressoa com essa literatura quando observamos que a ascensão do movimento feminista e feminino, assim como a produção científica sobre o assunto, se fortalece à medida que o regime ditatorial brasileiro perde poder.

Pereira (2017) aponta para outro elemento no contexto político que tem impacto significativo na institucionalização do EMGF, que é a força e estrutura dos movimentos feministas e o grau em que são/foram favoráveis 
A institucionalização dos estudos de mulheres, gênero e feminismo em tempos de ditadura militar | Gabriela de Brito Caruso

ao desenvolvimento da pesquisa e educação feminista na academia (Barazzetti e Leone, 2003; Chen, 2004; Silius, 2002). Além disso, a autora expõe como os trabalhos sobre o assunto (Bazzaretti e Leone, 2003; Góngora, 2002; Silius, 2002) mostram que o acesso ao apoio financeiro de governos, financiadores privados, ONGs estrangeiras/internacionais ou órgãos intergovernamentais (como as Nações Unidas) pode facilitar a fundação de cursos, centros, periódicos e redes internacionais dos EMGF. O segundo fator contextual relaciona-se com essa literatura na medida em que considero a posição dos movimentos feministas/de mulheres e suas influências internacionais como essenciais para o tipo de estratégias desenvolvidas nos EMGF.

O terceiro fator contextual que coloco é sobre a institucionalização e expansão das Ciências Sociais, bem como à reforma educacional do período militar. Os estudos analisados por Pereira (2017) demonstram que as iniciativas de institucionalização são mais eficazes quando lideradas por acadêmicos que têm acesso a valiosos recursos e espaços em seus campos, ou possuem poderosos aliados e rede nacional/internacional de apoio, podendo mobilizá-las para reforçar a credibilidade da área. A autora também destaca que em contextos em que a comunidade acadêmica é mais rigidamente disciplinar, geralmente há menos apoio aos EMGF e o campo tende a ser formalizado como parte de disciplinas existentes e não como um campo autônomo (PEREIRA, 2017).

De acordo com Albertina de Oliveira Costa (1994), a área, desprovida de sinais externos de identidade e de contornos fluídos, é constituída por uma comunidade de pesquisadores que partilha um interesse por um tema sem um elo formal, desenvolvendo-os em objetivos e projetos comuns a partir de uma rede informal de laços de solidariedade e apoio. É o que a autora chama de "estratégia da corda bamba" (1994), uma tentativa de encontrar um ponto de equilibro, com as vantagens (aglutinação e potencialização dos esforços, captação de recursos) mas sem as desvantagens da institucionalização (segregação), promovendo uma "institucionalização soft" (1994, p. 3). A estratégia privilegia a abertura, a integração e a flexibilidade, aproveitando as brechas e conquistando espaços meio as disciplinas tradicionais. De maneira geral, as acadêmicas 
A institucionalização dos estudos de mulheres, gênero e feminismo em tempos de ditadura militar | Gabriela de Brito Caruso

identificavam-se com suas disciplinas tradicionais e procuraram se integrar a dinâmica da comunidade científica nacional mediante a obtenção do reconhecimento do valor científico das suas preocupações intelectuais pelos profissionais das Ciências Sociais (HEILBORN, SORJ, 1999).

Costa também indica que este lugar dual ocupado pelos EMGF é resultante de uma rejeição ao que ela denomina uma "inclinação separatista" (COSTA, 1994, p. 3), preferindo a busca por uma transversalidade que afirmaria a onipresença "das hierarquias sociais baseadas no sexo" (COSTA, 1994, p. 3) nas diferentes disciplinas em oposição a demarcação de um território separado. Costa não deixa explícita sua opinião sobre este tema, mas implícito na sua escolha de palavras (como 'separatista') tem um favorecimento a estratégia que ficou conhecida como "mainstreaming", as vezes chamada de "integração", de estar presente em todos os campos sem que seja necessário um corpo próprio formalizado.

Meu argumento é que a opção pela estratégia de "integração" ou "mainstreaming" não se dá por uma falta de radicalidade (HEILBORN, SORJ, 1999) ou por ser um "feminismo bem comportado" (COSTA, 1988; PINTO, 2014), mas se dá no contexto das lutas pela democratização e das alianças político-intelectuais traçadas neste momento. Nesse sentido, o que se faz é aproveitar a recém-construída legitimidade das Ciências Sociais - e, em particular neste estudo, da Sociologia, que nos anos 1950 viveu seu período de institucionalização e de profissionalização - para legitimar junto à comunidade científica o novo tema que surgia do ambiente "ideológico" e militante dos movimentos sociais e das experiências pessoais de exílio e estudo no exterior.

\section{O regime militar e a repressão}

Com ampla produção a respeito, vou dirigir-me agora às relações do movimento de mulheres, do movimento feminista e seu braço acadêmico durante o regime ditatorial militar. É importante lembrar que nem todo movimento de mulheres se entende como feminista ainda que com frequência teçam relações próximas de aliança ou conflito. É neste sentido que Joana Pedro (2006) nos chama atenção para como se constituem as narrativas fundadoras do feminismo no Brasil. 
A institucionalização dos estudos de mulheres, gênero e feminismo em tempos de ditadura militar | Gabriela de Brito Caruso

O fortalecimento do feminismo no Brasil na década de 1970 conta com sua própria disputa de narrativas, por isto é preciso estar atento ao direcionar nosso olhar para este momento, entendendo que as fontes (sejam textos acadêmicos ou entrevistas) estão construindo suas narrativas a partir de perspectivas localizadas em seu meio. Assim sendo, um dos primeiros localizadores do conhecimento então produzido é a centralidade (comum na academia Brasileira) da região sudeste como pioneiro e fator explicativo que é ou ampliado para todo o país ou localizado como centro irradiador de influência. Outro viés importante de mencionar é que esta produção bibliográfica foi, em grande parte, feita por mulheres intelectuais, estabelecidas academicamente e com trajetórias profissionais de sucesso. Isto implica reconhecer essas mulheres como pertencentes a um grupo privilegiado em termos de classe, parte da elite intelectual do país. Com frequência esta produção vai refletir suas experiências pessoais e coletivas e, portanto, reproduzir seus vieses. Isto talvez nos ajude a entender por que essa bibliografia não deu centralidade às relações entre raça e gênero, como fez com a relação de classe e gênero.

De qualquer maneira, o cenário de fortalecimento do feminismo e do movimento de mulheres organizado no Brasil ocorre numa conjuntura muito específica na região: durante o início dos anos 1970, quando o país vive sob um Regime Militar e no espírito do milagre econômico. Junto à reforma universitária no final dos anos 60, ocorre o aumento violentíssimo da repressão do Estado contra seus inimigos internos. Como nos chama atenção Costa (1988), nessas condições se abrem possibilidades de ascensão social para um setor educado e qualificado pelas camadas médias, ao mesmo tempo em que é cerceado pelo aparato repressivo.

A literatura parece concordar, em geral, que a luta contra a ditadura diluiu as diferenças e impediu a autonomização de distintas tendências no feminismo brasileiro, fazendo com que as mais clássicas abordagens (libertária radical e igualitária liberal) não encontrassem aqui terreno para se reproduzir (COSTA, 1988; HEILBORN, SORJ,1999; SARTI, 2001). O argumento de Pedro (2006) é de que as experiências do feminismo e movimento de mulheres organizado no Brasil passa necessariamente, ainda que não se esgote, no campo da esquerda e na luta pela democracia. 
A institucionalização dos estudos de mulheres, gênero e feminismo em tempos de ditadura militar | Gabriela de Brito Caruso

A respeito de como se construiu a área de estudos:

o campo de estudos sobre a mulher se constituiu de maneira empírica, ao sabor dos acontecimentos com feições de circunstância e sem grandes preocupações com definições teóricas (COSTA, 1988 apud FARGE, 1983).

Nos anos 1960 a mulher já adquiria maiores liberdades, aceleradas por um contexto de industrialização que vinha ocorrendo, mais presente no mercado de trabalho e nas universidades que se expandiam. Este cenário gerou, ainda que de forma excludente, novas oportunidades para alguns grupos de mulheres, especialmente das classes médias e altas e de cor branca. Como bem coloca Sarti (2001), este processo foi acompanhado pela efervescência cultural crítica de 1968, que favoreceu o acesso a métodos contraceptivos, abrindo caminho para novos comportamentos afetivos e sexuais, ampliando acesso a terapias psicológicas e a psicanálise, que combinados estavam alterando o padrão tradicional dos valores familiares.

Outro exemplo de mudanças nos papéis tradicionais de gênero que vinham ocorrendo no Brasil se deu no próprio seio da luta dos segmentos de esquerda em relação ao governo autoritário. Para Sarti (2001), a presença das mulheres na luta armada no Brasil dos anos 1960 e 1970 era neste caso uma subversão tanto da ordem política quanto ao que era designado próprio para as mulheres à época. Sem uma elaboração feminista deliberada, as militantes estariam subvertendo o lugar tradicionalmente atribuído à mulher ao pegar em armas para resistir à ditadura. $O$ feminismo não era necessariamente algo tão óbvio para este grupo de mulheres à época. Muitas se entendiam como mulheres emancipadas em uma sociedade em mudanças aceleradas, sem nunca terem ocupado os papeis femininos mais tradicionais, pois estudavam e trabalhavam em meio aos homens (COSTA, 1988). Se identificavam mais com as dinâmicas masculinizadas da política e da ciência e desprezavam os assuntos tradicionais típicos femininos. Eram mulheres com carreiras já amadurecidas ou em vias de amadurecimento na trajetória como professoras, doutoras e com participação na militância politica. Eram parte de uma minoria tão privilegiada, com ensino superior, que com frequência alegavam não sentir sobre si nenhum impeditivo pelo fato de ser mulher. Não é de se espantar que o conceito de classe tivesse tanta proeminência em relação ao de gênero neste campo político-intelectual. 
A institucionalização dos estudos de mulheres, gênero e feminismo em tempos de ditadura militar | Gabriela de Brito Caruso

O mesmo ano de 1968 traz dois aspectos do regime político ditatorial que influenciaram a configuração dos EMGF no Brasil: a Reforma Universitária e o Ato Institucional n.5 (AI-5). A Reforma de 1968 se destaca pelo foco na formação de quadros de alto nível, pela valorização da pesquisa e pelo desenvolvimento das ciências voltado as novas tecnologias e ao conhecimento aplicado para o crescimento econômico do país. As reformas são discutidas em um momento de controle político e ideológico da educação, com diminutos recursos públicos e a associação direta da educação aos interesses do capital. Apesar da expansão, o braço repressivo do Estado invadia e intervia nas universidades depondo reitores, aposentando compulsoriamente ou demitindo professores e entrando em salas para prender estudantes e docentes críticos ao regime.

Como resposta ao recrudescimento do regime militar, eclodem grandes manifestações estudantis e se intensifica a opção da luta armada. A Reforma Universitária e a institucionalização da pós-graduação se deram também como parte de uma tentativa de atender a algumas demandas antigas e retirar das universidades o foco da resistência ao regime. A Reforma teve este duplo carácter de desmobilização política dos estudantes e de uma racionalização acadêmica, administrativa e tecnicista em sua estruturação (ALVES e OLIVEIRA, 2014, colocando a pesquisa como uma das dimensões indissociáveis do trabalho docente na educação superior.

Houve então um rápido crescimento da pós-graduação, pensada como uma política de Estado, tendo função de contribuir para o desenvolvimento econômico-produtivo, sendo pensada pelo seu valor estratégico no processo de desenvolvimento econômico do país. Com inspiração na estrutura universitária dos Estados Unidos (SAVIANI, 2008), são extintas as cátedras e os departamentos passam a ser entendidos como a menor fração da estrutura universitária, com professores trabalhando em regime de dedicação exclusiva.

Este cenário se torna propício para a criação de núcleos de estudos, concentrados na pesquisa acadêmica e pouco favoráveis a empreitadas críticas emancipatórias pela via do ensino. Com um entendimento técnico, prático e científico da produção universitária em um cenário de perseguição ideológica, a busca por legitimidade se faz mais segura recorrendo ao 
A institucionalização dos estudos de mulheres, gênero e feminismo em tempos de ditadura militar | Gabriela de Brito Caruso

reconhecimento de disciplinas tradicionais ao invés da reivindicação de um novo campo crítico ao sistema de saberes.

Outro aspecto do regime político ditatorial que influenciaria a configuração do feminismo no Brasil, segundo Costa (1988), é o vazio político que se instala após a aniquilação da resistência armada pelo aparato repressivo. O AI-5 autorizava o presidente da República, em caráter excepcional, logo sem apreciação judicial, a decretar o recesso do Congresso Nacional; intervir nos estados e municípios; cassar mandatos parlamentares; suspender, por dez anos, os direitos políticos de qualquer cidadão; decretar o confisco de bens considerados ilícitos; e suspender a garantia do habeascorpus. O Congresso Nacional entrou em recesso por tempo indeterminado e a esquerda passa então pelo processo classificado por Rezende (2010, p. 41) de "depleção", que significaria, em sentido metafórico, a perda de elementos fundamentais do organismo, um estado de esgotamento provocado pela perda excessiva de sangue.

Nesse contexto, na virada pra década de 70 , a vida política estava resumida à sobrevivência dos opositores. Segundo Costa (1988) é essa sensação de vazio (oposta à agitada vida política, aonde há sempre o que fazer) que marca o sentimento das primeiras ações feministas. Essa sensação se refere ao esvaziamento dos canais políticos tradicionais, com a censura aos jornais, a dissolução dos partidos políticos existentes e a permanente ameaça de cassação dos direitos políticos dos que ainda atuavam no cenário partidário (CORRÊA, 2001). Se a arena do debate público, tradicional espaço dos homens, estava fechada, o privado, associado ao feminino, se tornava o espaço alternativo de reflexão. De acordo com Sarti (2001), o movimento feminista organizado vem com o sentido de elaborar politica e pessoalmente esta derrota.

É neste cenário que se criam os grupos de reflexão. $\mathrm{Na}$ impossibilidade do exercício político, as reuniões acessavam um nível além do individual e provocavam uma reflexão coletiva. Eram grupos reunidos dentro das casas, que impossibilitados de irem às ruas devido ao acirramento do regime político, se realizavam no âmbito do privado. O medo da ação política se dá pelo trauma da repressão enquanto opositoras do regime autoritário e o terror impede a ação coletiva de colocar a cabeça pra 
A institucionalização dos estudos de mulheres, gênero e feminismo em tempos de ditadura militar | Gabriela de Brito Caruso

fora. Essa atividade era entendida como atividade privada, caseira, doméstica, que são, inclusive, características atribuídas ao feminino. Os grupos de reflexão pensavam sua atividade como hibernal, como uma preparação para futura ação política com P maiúsculo (COSTA, 1988).

De acordo com Pedro (2006), as principais narrativas fundadoras do feminismo da década de 1970 se expressaram nas disputas de poder dentre os diferentes grupos feministas e suas relações com os diversos personagens envolvidos na luta contra a ditadura militar, instalada no país entre 1964 e 1985. De maneira geral, as disputas eram lidas segundo as dicotomias "lutas gerais e lutas especificas", de um lado, e "verdadeiramente feministas e não-feministas", de outro (PEDRO, 2006).

Enquanto esta última destaca os grupos de reflexão, a outra coloca como marco a fixação da Organização das Nações Unidas (ONU) do ano de 1975 como o Ano Internacional da Mulher, bem como o marco de início da Década da Mulher, que teria reacendido no Brasil o movimento feminista organizado. Segundo esta narrativa, é a partir de 1975 que surgem os grupos politicos de mulheres que encabeçarão o movimento até os anos 80 . Este teria sido inaugurado com uma reunião, em julho de 1975, na ABI (Associação Brasileira de Imprensa), no Rio de Janeiro, que levou a constituição do Centro da Mulher Brasileira na mesma cidade (PEDRO, 2006).

É importante lembrar que não se deve simplificar analiticamente e tomar automaticamente o movimento de mulheres como feminista. Haviam muitas mulheres organizadas nos movimentos que não se consideravam feministas e muitas feministas que não necessariamente se engajaram nos movimentos de mulheres. É inevitável, no entanto, que por vezes o movimento feminista e o movimento de mulheres se sobreponham e compartilhem de uma grande intersecção.

No contexto político brasileiro de repressão as oposições, qualquer reunião, especialmente de grupos constantemente vigiados, constituía um risco muito grande e o Ano Internacional da Mulher, com apoio da ONU, permitiu que houvessem grandes encontros e eventos que discutiam direitos sem as constantes e truculentas intervenções da polícia militar. Nesta narrativa, o fortalecimento do movimento de mulheres e feminista de 1975 
A institucionalização dos estudos de mulheres, gênero e feminismo em tempos de ditadura militar | Gabriela de Brito Caruso

com o apoio da ONU, teria aberto um espaço de reorganização para partidos e grupos políticos clandestinizados pela repressão do regime ditatorial. Segundo Pedro (2006), ao mesmo tempo que era entendido como uma oportunidade de reunião e estruturação em favor da democracia, o movimento de mulheres também foi pensado como uma ameaça ao projeto político de muitos desses grupos, pois poderia significar uma divisão e dispersão daquilo que consideravam ser a luta prioritária. O contexto, portanto, era favorável à discussão da condição feminina, ainda que de maneira geral as ditaduras latino-americanas promovessem a censura e a perseguição a seus opositores.

O feminismo no Brasil, quando entendido em um sentido mais restrito $^{3}$, foi de certa maneira gestado nas elites intelectuais, por mulheres que tiveram acesso à universidade, em vias de profissionalização e de certa maneira familiarizadas ao estilo de vida propiciado pela modernização excludente característica daquele período (SARTI, 2001). Com relação ao regime militar e a repressão por ele organizada, as narrativas mais tradicionais do EMGF destacam algumas dualidades importantes. Em primeiro lugar em relação as mudanças econômicas mais gerais que vinham ocorrendo desde antes do regime, com a industrialização, a modernização e uma maior inserção das mulheres no mercado de trabalho e nas universidades. Estas mudanças foram marcadas pela desigualdade de classe e raça, dando maiores possibilidades a grupos privilegiados. Nesse sentido, as narrativas dos EMGF passam tanto pelas restrições políticas do regime militar quanto pelas alterações em relação aos papéis femininos. Isto muitas vezes aparece como uma justificativa para o foco do movimento nas "questões gerais" e para a alcunha de "feminismo bem comportado" (COSTA, 1988; PINTO, 2014) com sua "falta de radicalização" em relação a pautas feministas dos contextos europeu e norte-americano, como na questão da preponderância da luta de gênero sobre a luta de classes e na liberação sexual, como veremos adiante.

\footnotetext{
3 Em "Feminism without borders", Mohanty olha o feminismo como operante em distintos niveis da vida social. O primeiro na vida cotidiana, constituindo nossas identidades e relações; o segundo nos movimentos coletivos, em grupos e redes com uma visão feminista de transformação social; e o terceiro no nível da teoria, pedagogia, criatividade textual e acadêmica de feministas engajadas na produção de conhecimento. Aqui me refiro restritamente a este último nível.
} 
A institucionalização dos estudos de mulheres, gênero e feminismo em tempos de ditadura militar | Gabriela de Brito Caruso

\section{A resistência e os movimentos sociais}

Trazer à tona a importância contextual do regime militar para o movimento feminista e para os EMGF não serve apenas como salvaguarda às comparações feitas entre o caso brasileiro com o feminismo nos EUA e na Europa, mediante a evocação de uma especificidade terceiro-mundista. O que essa narrativa traz consigo, a reboque ou conscientemente, é a alternativa terceiro-mundista dos projetos de emancipação a partir de uma experiência do capitalismo subdesenvolvido.

O movimento de mulheres, em parte pela influência marxista e o trabalho de base das militantes, adquiriu uma articulação com as camadas populares e suas organizações de bairro assumindo uma composição mais interclasses (SCHMINK, 1981). Segundo Sarti (2001), essa atuação conjunta é uma marca do movimento no Brasil e lhe imprimiu características próprias, principalmente pela delicada relação com a Igreja Católica, que no já citado vazio político deixado pela ditadura também se tornou um importante foco de oposição.

No argumento de Céli Pinto (1992), é via movimento social que a mulher se constrói enquanto sujeito no interior da sociedade civil brasileira. Segundo Silva (2000), na conjuntura conservadora de um regime militar, as mulheres passaram a atuar em um campo privilegiado de luta, a partir do mundo da intersubjetividade, do cotidiano, o que vai estabelecer uma nova relação entre subjetividade e cidadania.

Neste momento as organizações femininas de bairro ganhavam força, principalmente com a influência do trabalho pastoral realizado pela Teologia da Libertação. De acordo com Sarti (2001) isto teria colocado os grupos feministas politizados e a Igreja em disputas pela hegemonia dentro dos grupos populares. Entretanto, como já sinalizamos, na superficie mantinhase uma política de alianças entre o feminismo, outros setores da esquerda e setores da Igreja Católica contra o regime autoritário:

Desacordos sabidos eram evitados, pelo menos publicamente. O aborto, a sexualidade, o planejamento familiar e outras questões permaneceram no âmbito das discussões privadas, feitas em pequenos "grupos de reflexão", sem ressonância pública (SARTI, 2001, p. 38). 
A institucionalização dos estudos de mulheres, gênero e feminismo em tempos de ditadura militar | Gabriela de Brito Caruso

Nesse sentido, a hegemonia da Igreja sobre os grupos populares, seguindo o argumento de Alvarez (1990), Moraes (1996) e Sarti (2001), determinou os limites do conteúdo ideológico da luta das mulheres, promovendo a participação das mulheres na vida comunitária através dos seus papéis familiares tradicionais.

Esta articulação entre gênero e classe não só perpassa a história dos movimentos de mulheres no Brasil mas também se manifestou nos EMGF a partir da influência marxista das pesquisadoras da área. Não é por coincidência que o tema "Mulheres no Trabalho" passa a ser um dos mais desenvolvidos nas pesquisas sobre gênero nas Ciências Sociais naquele momento, especialmente na sociologia. O Encontro Anual da Associação Nacional de Pós-Graduação e Pesquisa em Ciências Sociais (ANPOCS), maior congresso nacional da área, contou desde muito cedo com um Grupo de Trabalho intitulado "Mulher na Força de Trabalho", iniciado em 1979 e tendo perdurado por ao menos uma década. Como afirma Sarti (2001) evocando Moraes (1996), entre a luta contra as condições objetivas de opressão social e a reflexão em torno das relações interpessoais, o feminismo brasileiro estava a todo tempo articulando sua base marxista com a questão da subjetividade, refletindo a influência da psicanálise na formação dessas pesquisadoras.

De certa maneira, a narrativa que coloca o evento da ONU como central vê o órgão como catalisador deste processo que tem início 1975, quando a ONU realizou uma conferência internacional sobre a Mulher no México. O evento no Brasil foi realizado alguns meses depois, patrocinado pelo Centro de Informação da ONU sob o título "O papel e o comportamento da mulher na realidade brasileira". Segundo Pedro (2006), ter participado do evento passou a garantir certa legitimidade da identificação com o feminismo.

De acordo com Céli Pinto (2003), organizado por mulheres dos grupos do Rio de Janeiro com histórico de oposição ao regime, a capacidade organizativa do movimento se dava através das relações próprias da trajetória social e cultural de suas participantes, pertencentes à classe média intelectualizada com experiência internacional e rede de contatos que permitia iniciativas desse escalão. O nome do evento remete a uma seriedade 
A institucionalização dos estudos de mulheres, gênero e feminismo em tempos de ditadura militar | Gabriela de Brito Caruso

analítica e deliberadamente não inclui a palavra "feminista" que, segundo uma das organizadoras, assustava as pessoas (PINTO, 2003). O evento contou com a presença não só de feministas ligadas à esquerda e a outros segmentos de mulheres organizadas/intelectuais mas também contou com os nomes de muitos homens notáveis em sua programação. Eram maneiras de se fazer perceber menos políticas e adotar uma postura mais próximas a neutralidade característica dos discursos científicos, já que o regime impunha medo e perseguia o conteúdo concebido como ideológico. Era também uma estratégia consciente de se legitimar através do estabelecimento de alianças amplas com figuras de autoridade e liderança em diversos campos politico-intelectuais, se blindando de ataques dos mais diversos setores. É neste aspecto que o transnacional aparece como fator importante na construção de um status epistêmico legítimo para os EMGF: o financiamento da ONU ajudava a imprimir esta imagem técnica e científica ao evento.

O evento é entendido como um marco de organização do movimento de mulheres, tendo surgido dele, por exemplo, a experiência do Centro da Mulher Brasileira (CMB). O que se pode observar a partir do mote do evento e dos objetivos do CMB é sua inclinação analítica e científica na medida em que se buscava uma investigação legitima de questões pertinentes à mulher. O CMB tinha por objetivo o "estudo, a reflexão, pesquisa e análise" das questões da mulher, e a "criação de um departamento de ação comunitária para tratar concretamente e em nivel local dos problemas da mulher" (PINTO, 2003, p. 58).

Aqui já podemos notar nas escolhas de palavras como a questão da mulher é abordada pela via das pesquisas acadêmicas e dos métodos científicos, compatíveis com o conhecimento produzido pela universidade. Fica claro também o cuidado das organizadoras em passar uma seriedade no tratamento do tema digna do mundo acadêmico. Estas são estratégias para garantir legitimidade em relação à área, tentando estender sua capacidade de aceitação e de construção de alianças, ao mesmo tempo que funcionam para evitar a atenção dos agentes da repressão.

A escolha de fundar o CMB, uma instituição com estatuto legal e público, de acordo com Pinto (2003), estava associada à preocupação de não 
A institucionalização dos estudos de mulheres, gênero e feminismo em tempos de ditadura militar | Gabriela de Brito Caruso

dar margem a suspeitas de que poderia estar se organizando algo clandestino ou pouco aceitável. De maneira geral, segundo a autora, no CMB todas as mulheres se diziam feministas e contra o regime militar, mas de grosso modo se dividiam em dois polos: as que identificavam uma problemática específica das mulheres; e as que viam a questão da mulher sobredeterminada pela questão de classe.

Um diagnóstico comum que o campo da esquerda fazia para justificar o apoio popular ao governo militar era a falta de uma tradição democrática no país. Neste caso, a interpretação era que o papel das camadas médias 'esclarecidas', organizadas em partidos politicos na clandestinidade, se concentrava em se aproximar e conscientizar as camadas populares. Segundo Pedro (2006), a retomada do feminismo no Brasil sob a proteção da ONU foi encarada como uma oportunidade de realizar essa 'conscientização' das camadas populares, sendo o movimento feminista um passaporte para essa atuação. O campo da esquerda encontra uma entrada para a 'conscientização das classes populares' através das mulheres e neste bojo é que se constitui os movimentos de mulheres pela campanha da anistia dos presos e exilados políticos do governo militar, por direitos sociais e pela redemocratização.

Os grupos feministas tinham sua origem social nas camadas médias e altas intelectualizadas, mas sua visão e ação política objetivavam a transformação da sociedade como um todo. Sarti (2001) entende que este enfoque corroborou a articulação de suas pautas às demandas femininas mais amplas, tornando-as próprias do movimento geral das mulheres brasileiras. A palavra "feminista" tinha uma conotação extremamente pejorativa, seja na direita ou na esquerda. Como coloca Sarti (2001), a direita via o feminismo como imoral e perigoso e a esquerda via como reformismo burguês. Para ambos os lados, no entanto, entre mulheres e homens, o feminismo era essencialmente anti-feminino.

Corrêa (2001) salienta que as feministas recém-organizadas, apesar da homogeneização na representação da imprensa, eram tão atravessadas por dissensões politicas quanto quaisquer outros grupos. O que essa narrativa ligada aos partidos então clandestinos de esquerda não considera é a trajetória de feministas que não se situavam exatamente no campo da 
A institucionalização dos estudos de mulheres, gênero e feminismo em tempos de ditadura militar | Gabriela de Brito Caruso

esquerda partidária, ou de feministas liberais. Alguns anos antes, em 1972, a advogada e feminista de longa data Romy Medeiros havia realizado um congresso promovido pelo Conselho Nacional da Mulher voltado à discussão da "situação da mulher". Em 1962, Romy foi autora da revisão do status da mulher casada no Código Civil Brasileiro, assessorando a Federação Brasileira do Progresso Feminino e alterando a condição subordinada que a mulher tinha ao marido segundo a letra da lei. Em 1977 foi a autora intelectual da lei do divórcio no Brasil.

De acordo com o Pedro (2006) uma das explicações para que o evento e para que Medeiros não figurem na narrativa de ressurgimento do feminismo no Brasil na década de 70 era que Romy tinha boas relações com as elites do governo militar. Nesse sentido, a narrativa apresentada privilegia os marcos do feminismo que tem relação estreita com os grupos de esquerda.

Mesmo nas iniciativas de intelectuais de boa relação com o regime, como Romy, as iniciativas feministas não eram bem recebidas pela repressão. Segundo Pedro (2006) a própria Romy Medeiros enfrentou dificuldades para realizar o congresso de 1972, tendo sido chamada várias vezes ao Departamento de Ordem Política e Social (DOPS). ${ }^{4}$

No cenário das disputas da esquerda, as lealdades eram muito diversificadas, normalmente vinculadas à Igreja, ao Partido, ou à Universidade. Como afirmamos, o feminismo entra no debate no Brasil via mulheres com trajetórias sociais bem específicas, como profissionais com educação universitária, pertencendo a camadas sociais com experiência de vida cosmopolita. Sarti (2001) então nos chama atenção para a desigualdade de acesso aos recursos de ordem simbólica característicos do lugar aonde desponta o pensamento feminista. A relação da mulher com o homem, o casamento e a maternidade, são experiências com fortes marcas culturais que variam não somente no espaço/tempo mas também de acordo com a classe social das pessoas, o que propicia um vasto leque de experiências e perspectivas que leva a diversas possibilidades de identificação com as bandeiras feministas (SARTI, 2001).

4 Órgão do governo brasileiro utilizado durante o Estado Novo e na Ditadura Milita que tinha a função de assegurar e disciplinar a ordem militar no país. 
A institucionalização dos estudos de mulheres, gênero e feminismo em tempos de ditadura militar | Gabriela de Brito Caruso

Se por um lado a censura e a repressão do governo limitavam as discussões, por outro as lutas de resistência também disputavam os terrenos apropriados de discussão. Nesse sentido, a esquerda marxistaortodoxa também tinha suas pautas prioritárias e isto limitava o campo de atuação e crítica feminista. Os principais ataques ao movimento no Brasil eram relativos ao feminismo que se desenvolvia nos Estados Unidos, criticando a tradução de livros feministas que focalizassem temas como sexualidade, contracepção e aborto (SARTI, 2001).

Para Anette Goldberg (GOLDBERG, 1991), o feminismo que se forjou no Brasil não poderia ter, como o da França, "um inimigo principal", que no feminismo internacional era o patriarcado (apud PEDRO, 2006). A luta, aqui, tinha de se fazer, ao mesmo tempo, contra a opressão capitalista e contra a opressão patriarcal. O que se queria era formar uma sociedade socialista feminista. E, justamente para combater esses dois tipos de opressão, era preciso ter "dupla militância” (PEDRO, 2006, p. 268).

Pedro (2006) entende que a luta feminista no Brasil, no campo da esquerda e em plena ditadura militar, traçava um projeto muito diferente daquele que se desenvolvia na Europa e nos Estados Unidos, de onde vinham os livros, as ideias e as propostas ${ }^{5}$. No argumento de Costa (1988), o feminismo "bem comportado" no Brasil desenvolveu algumas de suas características, pois nasceu em uma relação tensa com o aparato policial repressivo e em um regime autoritário, a vista de problemas graves de desigualdade social e fome, resultando em um movimento de reivindicação de direitos sociais. Este desenho também teria ficado explícito na Conferência Internacional da Mulher no México, em 1975, na oposição entre os posicionamentos das mulheres dos assim chamados "terceiro mundo", mais politizadas, e as do "primeiro mundo" (COSTA, 1988).

$\mathrm{O}$ que se começava a fazer é tentar se organizar pelas lutas democráticas, construir uma frente ampla com muitos apoios e alianças de partido, igreja, sindicato, associação de bairro e assim por diante (COSTA, 1988). A ideia então foi comemorar o Ano Internacional da Mulher unindo essas diferentes frentes para discutir a situação da mulher. Neste

\footnotetext{
5 Mais sobre as relações de trocas intelectuais e de influências entre feministas francesas e brasileiras, e sobre os grupos latino-americanos e de brasileiras em exílio na França, ver SCHUCK (2017).
} 
A institucionalização dos estudos de mulheres, gênero e feminismo em tempos de ditadura militar | Gabriela de Brito Caruso

contexto, a atividades das mulheres pareciam respeitáveis e promissoras. Não à toa foram um dos mais importantes contingentes na luta pela anistia, sendo as primeiras a se organizar e colocar a cabeça pra fora na vida politica.

A luta das mulheres no Brasil teria se manifestado mais no campo dos movimentos sociais, demandando do Estado direitos sociais e bens coletivos. Exemplos desta expressão é a luta pelas creches públicas, pela Anistia, por luz, asfalto e escolas. Todas são pautas que habitam o imaginário de "feminino" e sua relação com a reprodução e trabalho de cuidado da família. Este tipo de reivindicação, mais próxima e em consonância com que se entendia como o "universo" da mulher dava grande legitimidade ao movimento e suas reivindicações, obtendo sucesso em angariar apoio dos mais diversos grupos sociais. Estas pautas não abalavam o lugar mais tradicional das mulheres na vida privada ainda que as colocasse em cena no jogo político, rompendo com o papel tradicional das mulheres na vida politica. A estratégia consistia em se valer da sua experiência como mulher, mãe e esposa, como reprodutoras da vida política e social para legitimar suas demandas junto ao Estado.

Esta característica que Sarti (2001) aponta como diferença fundamental entre o movimento de mulheres no Brasil quando comparado ao dos países europeus, e eu adicionaria ao dos Estados Unidos: a relação entre os movimentos sociais urbanos e o Estado. Com uma organização local e imerso no cotidiano dos moradores das periferias pobres, o movimento de mulheres dirige suas demandas ao Estado, chamando-lhe ao seu papel de promotor de bem-estar social. Não à toa suas maiores reivindicações estão relacionadas à infraestrutura urbana básica (água, luz, esgoto, asfalto e bens de consumo coletivos), que como indica a autora, têm como parâmetro o mundo da reprodução - a família e suas condições de vida - que caracterizam a forma tradicional de identificação social da mulher (SARTI, 2001). Esta via não apenas se fazia necessária por ser uma demanda política urgente da sociedade, mas também eram pautas que podiam mobilizar amplas alianças de apoio a causa, entre Igreja católica e diversos setores da esquerda. 
A institucionalização dos estudos de mulheres, gênero e feminismo em tempos de ditadura militar | Gabriela de Brito Caruso

Enquanto na Europa e nos Estados Unidos se buscava reduzir a tutela do Estado sobre a individualidade da mulher, a tônica brasileira era reivindicar junto ao Estado o acesso aos bens sociais. Existe nesse contexto social e nessa conjuntura política uma diferença brutal entre o que se é produzido por uma literatura de circulação global sobre as mulheres e o feminismo, e como as brasileiras interpretam e o que produzem aqui. Como afirma Albertina de Oliveira Costa:

A questão da mulher é suficientemente ampla, suficientemente em
evidência e suficientemente legitima para que os partidos de
esquerda comecem a se interessar por ela. Começa a aparecer a
oposição entre a luta pelos direitos da mulher e os desvios do
feminismo, a conversa que vai durar anos entre femininas e
feministas. Entre a boa e a má luta da mulher (COSTA, 1988, p. 68).

A narrativa dos EMGF em relação à resistência à ditadura militar deixa bem claro sua oposição ao regime, o que contribui para várias de suas características. A primeira é uma vinculação política-intelectual com a esquerda de maneira geral e um apagamento de empreitadas feministas fora do espectro da esquerda. A influência marxista, o enfoque interclasse, a luta por direitos sociais e politicos e sua conformação como movimento social se apresentam não como "desvios" terceiro-mundistas dos feminismos gestados no primeiro-mundo, mas como alternativas legítimas resultantes dos legados e de suas genealogias.

Os desafios do contexto político também justificam a pouca visibilidade de algumas pautas consideradas tradicionais do feminismo, como o direito ao aborto, reforçando a necessidade de se construir alianças amplas com a esquerda, a igreja e as universidades para se opor ao regime. Previnem ainda às acusações comuns à época de que o feminismo seria um desvio burguês ou importação de um pensamento estrangeiro.

Realçando a relação do feminismo e do movimento de mulheres com o movimento democrático de resistência, os EMGF chamam para si o protagonismo desta luta. Esse posicionamento ajuda a garantir a legitimidade de suas lutas politicas e revela a importância de se pesquisar academicamente as mulheres como sujeitos politicos, econômicos e sociais com causalidade na vida social. Assim como evocar o evento da ONU como marco histórico traz o transnacional para dentro do jogo, fazendo do 
A institucionalização dos estudos de mulheres, gênero e feminismo em tempos de ditadura militar | Gabriela de Brito Caruso

prestígio das instituições transnacionais um importante trunfo na construção de sua legitimidade e status epistêmico.

\section{As narrativas na academia}

Se a luta politica trazia a relevância de se fazer pesquisa sobre mulheres, por outro lado, sua conjugação na individualidade com a atividade científica podia servir como obstáculo frente ao ideal de imparcialidade do intelectual. Para Heilborn e Sorj (1999) o esforço de construir uma problemática sociológica diferenciada do problema político trazido pelo feminismo caracteriza boa parte dos esforços de institucionalização. Apesar disso, esse processo foi marcado por disputas intensas entre grupos acadêmicos com diferentes visões sobre o que os EMGF deveriam ser.

Em 1975, na vigésima sétima reunião anual da Sociedade Brasileira pelo Progresso da Ciência (SBPC) em Belo Horizonte, conta Costa (1988), realizaram-se duas mesas sobre o tema "mulher" no mesmo dia. A narrativa da autora define dois tipos de visão sobre o significado e o lugar dos EMGF na academia. A composição das mesas era semelhante, professoras universitárias de gerações e círculos intelectuais próximos. Na mesa da manhã não foram apresentados artigos, a disposição das cadeiras era em círculo, de maneira e reduzir as diferenças entre expositores e ouvintes, desafiando as regras implicitas da produção e circulação acadêmica. A tarde, a outra mesa dispunha de textos sobre pesquisas em andamento que tinham a mulher como objeto e buscavam apresentar estudos empíricos da condição das mulheres, com palco e plateia: "A reunião da manhã era de feministas que também eram especialistas e a da tarde de especialistas que também era feministas" (COSTA, 1988, p. 67).

O evento narrado por Costa (1988) coloca dois projetos diferentes e visões distintas sobre os EMGF na academia. O primeiro grupo rompe com o espaço acadêmico tradicional, mas também evidencia uma concepção de separação dos espaços da política e da ciência, desaprovando o que seria o uso dos movimentos sociais para construção de uma carreira intelectual pessoal. O outro faz do feminismo pesquisa acadêmica e apoia-se na mesma para provar, a partir de suas regras especializadas, a validade das questões 
A institucionalização dos estudos de mulheres, gênero e feminismo em tempos de ditadura militar | Gabriela de Brito Caruso

postas, ressaltando sua competência a partir de suas credenciais de especialistas. De maneira geral:

Encontramos ainda de forma subjacente uma atitude que, se não é de rejeição, também não é de simpatia pela constituição de um campo autônomo dos estudos sobre [a] mulher. O propósito explícito e as inclinações pessoais iam mais no sentido de incorporar as questões de gênero às diferentes disciplinas (COSTA, 1988, p. 67).

Os maiores conflitos, no entanto, parecem ter se dado de forma interna aos grupos de mulheres, entre as pesquisadoras e entre os partidos de esquerda, ao invés de opor necessariamente as múltiplas filiações politico-intelectuais que este grupo de mulheres recém formado já nutria anteriormente. Ainda que os movimentos de mulheres tivessem uma relativa autonomia entre os grupos de esquerda, essa inserção no espectro político da esquerda e na oposição ao regime militar imprimiu certas características ao movimento. Prioridades, omissões, estilos de luta política e limites que não podiam ser ultrapassados foram influenciados por este cenário. Essas relações também se manifestaram de forma semelhante no meio acadêmico.

De acordo com Costa (1988), a academia não figurou como um dos alvos principais da critica feminista, não ocorrendo no Brasil o que aconteceu em outras experiências onde existiu uma oposição radical dos movimentos à academia tradicional. Um dos motivos que explica a relativa harmonia do movimento de mulheres e das feministas com a academia e a universidade era que estes eram um dos únicos locais aonde se podia discutir e produzir os modos de pensar caros à esquerda em um momento no qual o marxismo tinha grande influência, ainda que não absoluta. A oposição à ditadura militar colocava o espaço universitário de esquerda e os movimentos de mulheres e feministas em um mesmo campo políticointelectual. A universidade e o movimento de mulheres eram ativos cada qual em sua frente e muito vocais em sua oposição ao regime, o que os colocava taticamente como aliados contra o autoritarismo.

Apesar disso, as universidades eram o espaço das lutas gerais e abriam pouca possibilidade para o que eram consideradas lutas especificas das mulheres. Como afirma Albertina Costa: "Não houve contestação radical da universidade como espaço do saber dominante uma vez que se devia confirmar a legitimidade dos modos de pensar críticos aí desenvolvidos" 
A institucionalização dos estudos de mulheres, gênero e feminismo em tempos de ditadura militar | Gabriela de Brito Caruso

(COSTA, 1988, p. 68).

A universidade não representava um saber dominante que devia ser combatido mas um saber crítico que tinha que ser resguardado da intervenção militar como um espaço de organização das forças de oposição. Isto não significa que não houvessem críticas à estrutura universitária ou que não houvessem tensões com os estudos de mulheres, mas significa que se compartilhavam um mesmo campo político-intelectual em um cenário antidemocrático. Nesse sentido, as discordâncias e críticas mútuas, assim como os conflitos, se davam internamente e não se tornavam as prioridades, pois a prioridades já estavam impostas pela situação político-social.

Outro ponto mais ou menos pacífico na literatura sobre o tema no Brasil é a redemocratização ao longo da década de 1980, que se caracterizou por ser um momento de consolidação, especialização e tecnicização dos movimentos feministas. A anistia veio em 1979 e com isso retornam ao Brasil diversas mulheres que haviam sido exiladas e muitas das quais haviam experienciado o movimento feminista atuante na Europa. Além disso, como aponta Sarti (2001), a experiência de vida no exterior possibilitou que se convivesse com outro tipo de organização doméstica o que repercutiria tanto no âmbito pessoal quanto em sua atuação política. Este encontro e troca entre as que foram e as que ficaram foi proficuo para o movimento e determinante nas influências, canais e redes de circulação de conhecimento, algumas que perduram até hoje (ver SCHUCK, 2017).

De acordo com Corrêa (2001), a mesma euforia que estava nas ruas no final dos anos setenta, estava também na universidade. O contexto se tornava mais e mais favorável à discussão dos movimentos sociais e à discussão de ideias democráticas dentro e fora das salas de aula. Exemplo de como esta mudança no cenário político teve impacto na produção de conhecimento em torno das causas da mulher é o caso contado por Corrêa (2001): na Unicamp, um grupo de alunas e professoras da área de Ciências Sociais cria um núcleo de reflexão feminista e organiza em 1978, 1979, 1980, a "Semana da Mulher" na universidade, abrindo espaço para a pesquisa sobre mulheres naquela instituição.

Nos anos oitenta grupos feministas espalhavam-se pelos principais centros urbanos do país, reorganizando a sociedade e rearticulando relações 
A institucionalização dos estudos de mulheres, gênero e feminismo em tempos de ditadura militar | Gabriela de Brito Caruso

de poder (SILVA, 2000). Isto acarretou alguns ganhos importantes, por exemplo, o destaque dado ao debate em torno da violência contra a mulher inaugurou o atendimento às vítimas em delegacias especializadas. No final dos anos 80, quando se elaborava a nova constituição, um grupo forte de mulheres pressionava por direitos. Na mesma tendência à especialização, também ganhou mais força e legitimidade a pesquisa acadêmica sobre mulher, o que também foi acompanhado por um crescente interesse pelo tema no mercado editorial.

Com a redemocratização, a sociedade brasileira passava igualmente por um processo de modernização, o que providenciava um cenário favorável para a difusão das ideais feministas. De acordo com Sarti (2001), isto possibilitou uma significativa penetração do movimento feminista em associações profissionais, partidos, sindicatos, legitimando a mulher como sujeito social particular. Segundo Corrêa (2001), a euforia com o retorno de muitos exilados e da recriação dos canais políticos institucionalizados permitiu em 1979 um clima festivo de alianças que foram se tornando cada vez mais conflituosas a medida que desaparecia o inimigo comum e se abria um novo cenário democrático de disputas. Ainda que houvesse um maior espaço para discutir a opressão específica da mulher, o que Moraes (1996) aponta é que existe um processo de atomização dos grupos feministas, marcado por uma atuação mais especializada, com uma perspectiva mais técnica e profissional.

A abertura politica possibilita a criação de novos partidos políticos que rapidamente absorvem parte das mulheres organizadas, agora integrando os quadros do partido e cargos nas agências do governo. Outra parte significativa se estabelece nas Universidades. Alguns grupos decidem formar organizações não-governamentais (ONGs) e passam a usar suas redes de contato e mirar sua atuação para politicas públicas em áreas específicas, principalmente através dos canais institucionais.

Sarti (2001) aponta que a institucionalização do movimento se deu a partir de questões que respondiam às prioridades das agências financiadoras (como, por exemplo, aquelas relacionadas à saúde da mulher e aos direitos reprodutivos). É interessante aqui que a institucionalização do movimento, tanto quanto a produção de conhecimento ligada a ele se deu 
A institucionalização dos estudos de mulheres, gênero e feminismo em tempos de ditadura militar | Gabriela de Brito Caruso

não somente por dentro da academia, mas também pelas ONGs e no plano governamental, onde criaram-se conselhos da condição feminina, em todos os níveis, federal, estadual e municipal.

Como sinalizado em outras análises e também explicitado em Silva (2000), os anos noventa trouxeram uma dispersão aos movimentos feministas e uma flagrante institucionalização. Não só pelo crescimento das ONGs feministas mas na participação em fóruns nacionais e internacionais de discussão e nos aparelhos de Estado. Segundo Silva (2000), a especialização temática e a formação de redes também demonstram novas práticas sociais com trabalhos mais especializados, principalmente na saúde, direito, meio ambiente, violência, entre outros. De acordo com Silva (2000), grupos de trabalho em várias instituições do país (ligados às universidades ou independentes) tematizam as relações de gênero em diferentes áreas disciplinares. Como nos lembra Corrêa (2001), as trajetórias particulares nesse percurso do feminismo aos estudos de gênero só ganham sentido se avaliadas num contexto mais geral no qual a articulação entre militância politica, pesquisa acadêmica e cenário político-cultural sejam levados em conta. Muito embora mencione também a autora uma certa continuidade nestas trajetórias do feminismo aos EMGF, ao rememorar que muitas das mais legitimadas pesquisadoras atualmente são nomes que apareceram e ajudaram a fomentar estas discussões, manifestações, jornais, reuniões, grupos e reflexões nas décadas de 1970 e 1980. Isto nos mostra que alguns dos agentes que estiveram envolvidos com as lutas feministas da época foram também importantes para a constituição desse novo campo (CORRÊA, 2001).

Outro traço interessante no depoimento de Corrêa (2001) é o alerta que ela dá para a falsa impressão de que existiu uma imersão suave das feministas no meio acadêmico brasileiro, sinalizando o mal-estar que ainda hoje gera o interesse de pesquisa centrado nas mulheres. Para a autora há uma clara articulação entre o feminismo dos anos setenta e a emergência dos estudos de gênero nos anos noventa, assim como uma estreita vinculação entre as chamadas militantes e as pesquisadoras. Corrêa não concorda com a visão maniqueísta que separa militantes e pesquisadoras, 
A institucionalização dos estudos de mulheres, gênero e feminismo em tempos de ditadura militar | Gabriela de Brito Caruso

pois perde-se de vista que as pesquisadoras eram também militantes e militantes eram também produtoras de saberes.

De acordo com a autora, seria também preciso recuperar a história das pesquisadoras pioneiras do campo feminista e as dificuldades de sua inserção no campo das ciências sociais na época, mostrando que, longe de um apoio harmônico, havia desafios claros postos pelas convenções disciplinares da área. Em discordância da interpretação de Heilborn e Sorj (1999), de que a área de estudos de gênero no Brasil prescindiria de motivações políticas por ser primordialmente acadêmica, Corrêa (2001) afirma que a própria existência dos EMGF tinham uma dimensão política, mesmo quando não estivessem diretamente envolvidas com a militância. $\mathrm{O}$ que Corrêa faz é inserir na narrativa das autoras, de integração mais harmônica à academia, as disputas e cortes intelectuais entre as pesquisadoras dos EMGF e destas com a área mais ampla das Ciências Sociais.

De maneira geral, as narrativas sobre a relação dos EMGF com as instituições acadêmicas salientam esta relação dual de defesa da universidade com as ideias e teorias produzidas contra as investidas do governo militar, ao mesmo tempo que questionam vieses e pressupostos de um fazer científico masculinizado. A narrativa também privilegia a opção pelo "mainstreaming", ou seja, pela integração dos EMGF as disciplinas tradicionais, confiando sua legitimidade ao status científico das Ciências Sociais.

A construção de status epistêmico dos EMGF se dá pela via das disciplinas consagradas e se utiliza dos métodos científicos para legitimar a pertinência da área. Este movimento se faz pelo levantamento de dados, elaboração de estatísticas, trabalhos de campo, análises quantitativas e qualitativas, ou seja, a utilização de metodologia própria dos seus campos disciplinares para angariar junto aos pares a legitimidade perante o objeto. Contribuiu para isto o fato de muitas dessas intelectuais já estarem relativamente consolidadas em suas carreiras profissionais quando investiram neste assunto e terem formação acadêmica em centros de excelência, tanto no Brasil quanto no exterior. 
A institucionalização dos estudos de mulheres, gênero e feminismo em tempos de ditadura militar | Gabriela de Brito Caruso

\section{Considerações finais: status epistêmico nos EMGF no Brasil}

As narrativas acerca da institucionalização dos EMGF no Brasil esbarram e confundem-se com as dos movimentos de mulheres e movimentos feministas durante o período ditatorial militar. Como já apontamos, a literatura sobre institucionalização dos EMGF considera relevante para seu desenvolvimento a força e estrutura dos movimentos feministas e o grau em que são/foram favoráveis ao desenvolvimento da pesquisa e educação feminista na academia. Nesse sentido, vimos como a importância do movimento de mulheres na redemocratização do país ajudou a legitimar este tipo de produção intelectual.

Vimos também que as intelectuais brasileiras privilegiaram a institucionalização pela pesquisa em detrimento do ensino. São várias as possiveis explicações para que isto tenha ocorrido. A primeira é a reforma educacional da ditadura militar que institucionalizou e expandiu a pósgraduação no país, favorecendo e estimulando a pesquisa acadêmica. No contexto de enfrentamento ao regime militar, a universidade passa a ser vista como foco de subversão, mas os caminhos das pesquisas científicas estavam abertos pela expansão universitária, inclusive através de financiamento estrangeiro.

O segundo motivo que teria contribuído para esta configuração foi o cenário anterior de aumento da entrada das mulheres nas universidades e no mundo do trabalho. Com carreiras acadêmicas já mais ou menos estabelecidas e com experiências de pós-graduação nos Estados Unidos e Europa, a produção acadêmica sobre mulheres no Brasil é realizada em parte por pesquisadoras atuantes já enraizadas em suas áreas disciplinares (HEILBORN, SORJ, 1999). De acordo com nossa revisão da literatura, as iniciativas de institucionalização são mais eficazes quando lideradas por acadêmicos que têm acesso a valiosos recursos acadêmicos e espaços em seus campos, ou possuem poderosos aliados e rede nacional/internacional de apoio, podendo mobilizá-las para reforçar a credibilidade da área. Neste caso as acadêmicas se utilizaram de sua posição mais ou menos consolidada nas Ciências Sociais para legitimar a importância da pesquisa na área, e parte essencial desta estratégia era não abrir mão das teorias sociológicas e métodos científicos rigorosos que lhe garantiam um status epistêmico 
A institucionalização dos estudos de mulheres, gênero e feminismo em tempos de ditadura militar | Gabriela de Brito Caruso

científico, principalmente junto aos intelectuais de esquerda que viam no feminismo uma luta burguesa diversionista.

Consideramos também a importância do contexto do regime militar, sua repressão e a resistência a ele nas narrativas, o que limitava a luta em alguns sentidos, mas lhe dava contornos revolucionários em outros. Esta maneira de construir a história do feminismo no Brasil traz à tona a perspectiva da alternativa terceiro-mundista, do conhecimento produzido fora dos grandes centros de conhecimento e se conjuga às críticas à importação de pensamentos, teorias e movimentos do primeiro mundo. Vimos como a associação com o espectro político de esquerda trouxe a indispensabilidade da classe na discussão de muitas das feministas e como também servia para esquivar-se da acusação de divisionismo burguês. Da mesma maneira, os desafios de um capitalismo subdesenvolvido e um regime de cidadania restrita também justificaram a abdicação de temas e demandas considerados clássicos nos feminismos de primeiro mundo.

É bom notar que quando falamos de estratégia não nos referimos a um processo decisório que se dá explicitamente entre as diferentes pesquisadoras, que analisam a situação e optam por agir de certa maneira e não de outra. Primeiro que isto sugeriria uma homogeneidade e um centramento da intencionalidade que não se verifica naquele período. Estratégia, aqui, é pensada como o meio desenvolvido para atingir um objetivo, no caso, legitimidade científica. Penso que a estratégia empreendida é a resultante da causalidade específica do movimento das coletividades, uma causalidade coletiva que é irredutivel à ação dos indivíduos e aos fatores que previamente conformariam essa ação individual.

Especificamente na construção da legitimidade científica no campo, a estratégia resultante implica a compreensão das negociações e disputas institucionais e/ou discursivas dentro dos EMFG e destes com o jogo disputas mais amplas da academia. Apesar das clivagens, houve um impacto coletivo das pioneiras em seus esforços somados pela legitimação acadêmica em meio às disciplinas tradicionais das Ciências Sociais. O objeto, ou a área do EMGF só se legitimaria obedecendo aos marcadores de cientificidade, legitimidade confiabilidade das disciplinas consagradas. Quando se distancia 
A institucionalização dos estudos de mulheres, gênero e feminismo em tempos de ditadura militar | Gabriela de Brito Caruso

muito das convenções das Ciências Sociais é rapidamente associado a algo "politico" e "militante".

Em termos narrativos, a estratégia de legitimação científica de seu status epistêmico se dá pela reivindicação de estar produzindo Ciências Social, pesquisa qualificada, como pesquisadoras treinadas nas melhores instituições nacionais e internacionais. Como mencionamos, parte das mulheres que mais tarde produziram sobre a institucionalização dos EMGF no Brasil estavam vivendo e atuando naquele momento decisivo, portanto estavam imersas no jogo de disputas acadêmicas e mais tarde vieram a produzir suas narrativas a respeito.

No texto de Costa, Barroso e Sarti (1985), a representação da área como um limbo mostra o desconforto destas intelectuais, tanto na comunidade acadêmica quanto nos espaços de militância, onde ocupavam este meio lugar que não tinha status epistêmico privilegiado em nenhum dos dois mundos. Costa (1994) romantiza, em certa medida, a falta de formalização da área, que teria se desenvolvido de maneira despreocupada com formulações teóricas e por redes de afinidades com o tema. Nesta interpretação se escamoteiam as disputas intelectuais e a tomada de posição política dentro da academia que contribuem para uma visão menos militante da área uma vez que seria expressão de um interesse acadêmico desinteressado politicamente.

A maneira como os intelectuais se utilizam de práticas e discursos científicos para sustentar a sempre em construção legitimidade de status epistêmico de um conhecimento, só pode ser compreendida se levarmos em conta componentes de suas trajetórias intelectuais, e o contexto políticosocial em que viveram. Por isso é importante olhar não só para os processos de institucionalização da área, mas também para as posições e narrativas acerca destes processos e suas filiações mais amplas à intelectualidade e política da época para localizar as razões e os rumos dos EMGF no Brasil e assim pensar suas semelhanças e diferenças em relação a outros contextos.

\section{Referências:}

ALVES, Miriam Fábia, \& OLIVEIRA, João Ferreira de. Pós-Graduação no Brasil: do Regime Militar aos dias atuais [Online]. Rbpae, Vol.30, N.2, 
A institucionalização dos estudos de mulheres, gênero e feminismo em tempos de ditadura militar | Gabriela de Brito Caruso

2014.Disponivel

em: https://seer.ufrgs.br/rbpae/article/viewFile/53680/33095Acesso em: $24 / 04 / 2019$.

ALVAREZ, Sonia E. Engendering democracy in Brazil: women's movements in transition politics, 1990

BARAZZATTI, Donatella; LEONE, Mariagrazi. The Institutionalisation of Women ${ }^{\text {ee }}$ Studies Training in Europe. Report 2 project Employment and Women's Studies: The Impact of Women's Studies Training on Women's Employment in Europe, 2003. Disponivel em: http://www.hull.ac.uk/ewsi/ Acesso: 26/04/2019

BLAY, Eva Alterman. Trabalho domesticado: a mulher na indústria paulista. [S.1: s.n.], 1978.

BLAY, E.A., CONCEIÇÃO, R. R. A mulher como tema nas disciplinas da USP. Cad. Pesq, 1991

CHEN, Peiying. Acting "Otherwise": The Institutionalization of Women's/Gender Studies in Taiwan Universities. London: Routledge Falmer. 2004.

CORREAA, Mariza. Do feminismo aos estudos de gênero no Brasil: um exemplo pessoal. Cadernos Pagu, (16), 13-30, 2001. Disponível em: <https://doi.org/10.1590/S0104-83332001000100002>

COSTA, Albertina de Oliveira; BARROSO, Carmem \& SARTI, Cynthia. A pesquisa sobre mulher no Brasil: do limbo ao gueto? Cadernos de Pesquisa, 1985.

COSTA, Albertina de Oliveira. É viável o feminismo nos trópicos? Resíduos de insatisfação. Cadernos Pagu, 66, 63-69, 1988.

COSTA, Albertina de Oliveira. OS ESTUDOS DA MULHER NO BRASIL OU A ESTRATÉGIA DA CORDA BAMBA. Estudos Feministas, 2(N.E), 93-100, 1994.

FARGE, Arlette. Mouvements d'Histoire (à propôs d'um coloque surl'histoiredesfemmes). Bulletindu CRIF. Paris, (3):3-8, 1983.

FUNDAÇÃO CARLOS CHAGAS. Mulher brasileira: bibliografia anotada. São Paulo: FCC; Brasiliense, 1979. 279p.

FUNDAÇÃO CARLOS CHAGAS. Mulher brasileira: bibliografia anotada - 2. São Paulo: FCC; Brasiliense, 1981.

GOLDBERG, Anette. Le dire et le faire feministes: une approch e socioculturelle du Brésil Contemporain. Tese (Doutorado em História e Civilização) — Universidade de Paris VII. p.228-9, 1991. 
A institucionalização dos estudos de mulheres, gênero e feminismo em tempos de ditadura militar | Gabriela de Brito Caruso

GÓNGORA, Jimena Gallardo. Contradictions in the Institutionalisation Process of Women's and Gender Studies in Chilell in R. Braidotti, J. Nieboer and S. Hirs (eds.), The Making of European Women's Studies (Vol. IV). Utrecht: ATHENA/Universiteit Utrecht, 2002.

GROSSI, Miriam Pillar. (2004). A Revista Estudos Feministas faz 10 anos: uma breve história do feminismo no Brasil. Revista Estudos Feministas, 12(spe), 211-221. https://doi.org/10.1590/S0104-026X2004000300023

HEILBORN, Maria. Luiza; SORJ, Bila. Estudos de gênero no Brasil, em MICELI, Sergio. (org.) O que ler na ciência social brasileira (1970-1995). Sociologia (volume II), São Paulo, Editora Sumaré/ANPOCS, Brasília, Capes, 1999.

LOPES, Maria Margaret. \& PISCITELLI, Adriana. REVISTAS CIENTÍFICAS E A CONSTITUIÇÃO DO CAMPO DE ESTUDOS DE GENERO: UM OLHAR DESDE AS "MARGENS." Estudos Feministas, Florianópolis, 12(NE). 2004. Disponivel em: <https://doi.org/10.7213/estud.biol.36.SE.03>

MALUF, Sonia. OS DOSSIÊS DA REF: ALÉM DAS FRONTEIRAS ENTRE ACADEMIA E MILITÂNCIA. Estudos Feministas, 12(Especial), 235-243, 2004.

MORAES, Maria Lygia Quartim de. Vinte anos de feminismo. Campinas, Tesede Livre-docência, Departamento de Sociologia, IFCH/Unicamp, 1996.

MOHANTY, Chandra Talpade. Under Western Eyes: Feminist Scholarship and Colonial Discourses. Boundary 2 12(3):333-58, 1986.

PEDRO, Joana Maria. Narrativas fundadoras do feminismo: poderes e conflitos (1970-1978). Revista Brasileira de História, 26(52), 249-272, 2006. Disponivel em: <https://doi.org/10.1590/S0102$01882006000200011>$

PEREIRA, Maria do Mar. Pushing the Boundaries of Knowledge: An Ethnography of Negotiations of the Epistemic Status of Women's, Gender, Feminist Studies in Portugal. Tese de Doutorado, London School of Economics and Political Science, December, 2010.

PINTO, Céli Regina Jardim "Movimentos sociais: espaços privilegiados da mulher enquanto sujeito político" In COSTA, Albertina e BRUSCHINI, Cristina (orgs.) Uma questão de gênero. Rio de Janeiro/São Paulo, Rosa dos Tempos/Fundação Carlos Chagas, 1992.

PINTO, Céli Regina Jardim. Uma história do feminismo no Brasil. São Paulo: Fundação Perseu Abramo, 2003, p.58.

PINTO, Céli Regina Jardim. O feminismo bem-comportado de Heleieth Saffioti (presença do marxismo). Revista Estudos Feministas, 22(1), 321333, 2014. Disponivel em: <https://doi.org/10.1590/s0104026x2014000100017> 
A institucionalização dos estudos de mulheres, gênero e feminismo em tempos de ditadura militar | Gabriela de Brito Caruso

PISCITELLI, Adriana. BELELI, Iara. \& LOPES, Maria Margaret CADERNOS PAGU: CONTRIBUINDO PARA A CONSOLIDAÇÃO DE UM CAMPO DE ESTUDOS. Estudos Feministas, Florianópolis, 11(1), 242-246. 2003.

REZENDE, Claudinei Cássio de. Suicídio revolucionário: a luta armada e a herança da quimérica revolução em etapas. São Paulo: Cultura Acadêmica, 2010. ISBN 9788579830822 Disponivel em: <http://hdl.handle.net/11449/113723>

SAFFIOTI, Heleieth. A Mulher na Sociedade de Classe: Mito e Realidade. Petrópolis: Vozes, 1976 [1969].

SARTI, Cynthia. Feminismo e contexto: lições do caso brasileiro. Cadernos Pagu, (16), 31-48. 2001. https://doi.org/10.1590/S0104$\underline{83332001000100003}$

SAVIANI, Demerval. O Legado Educacional do Regime Miliar. Caderno Cedes. Campinas, SP, vol, 28, n,76, set/dez, 2008.

SCHMINK, Marianne. Women in the Brazilian "abertura" politics. Signs. Vol. 7, No. pp. 115-134, 1981.SCHUCK, Elena de Oliveira. Feminismos em movimento: mapeando a circulação do pensamento feminista entre Brasil e França. Tese, UFRGS, 175p. 2017. Disponivel em: http://hdl.handle.net/10183/168982

SILIUS, Harriet. Comparative Summary in G. Griffin (ed.), Women's Employment, Women's Studies, and Equal Opportunities 1945 - 2001: Reports from Nine European Countries. Hull: University of Hull, 2002.

SILVA, Susana Veleda da. OS ESTUDOS DE GÊNERO NO BRASIL: ALGUMAS CONSIDERAÇÕES. Revista Bibliográfica de Geografia y Ciencias Sociales.,262. 2000. Disponivel em: <https://doi.org/10.1360/zd-2013-43-6-1064> 